\title{
$\gamma$-Aminobutyric Acid and Benzodiazepine Receptors in the Kindling Model of Epilepsy: A Quantitative Radiohistochemical Study ${ }^{1}$
}

\author{
CHEOLSU SHIN, ${ }^{2 *} \S$ HELMER B. PEDERSEN,§ AND JAMES O. MCNAMARA` $¥ \S$
}

Departments of *Medicine (Neurology) and $\ddagger$ Pharmacology, Duke University Medical Center, and §Epilepsy Research Laboratory, Veterans Administration Medical Center, Durham, North Carolina 27705

\begin{abstract}
Quantitative radiohistochemistry was utilized to study alterations of $\gamma$-aminobutyric acid (GABA) and benzodiazepine receptors in the kindling model of epilepsy. The radioligands used for GABA and benzodiazepine receptors were $\left[{ }^{3} \mathrm{H}\right]$ muscimol and $\left[{ }^{3} \mathrm{H}\right]$ flunitrazepam, respectively.

GABA receptor binding was increased by $22 \%$ in fascia dentata of the hippocampal formation but not in neocortex or substantia nigra of kindled rats. Within fascia dentata, GABA receptor binding was increased to an equivalent extent in stratum granulosum and throughout stratum moleculare; no increase was found in dentate hilus or stratum lacunosummoleculare or stratum radiatum of CA1. The increased binding was present at $24 \mathrm{hr}$ but not at 28 days after the last kindled seizure.

The direction, anatomic distribution, and time course of the increased GABA receptor binding were paralleled by increased benzodiazepine receptor binding. Unexpectedly, GABA receptor-mediated enhancement of benzodiazepine receptor binding was slightly attenuated in fascia dentata of kindled compared to control rats.

The anatomic distribution of the increased GABA receptor binding is consistent with a localization to somata and dendritic trees of dentate granule cells. We suggest that increased GABA and benzodiazepine receptor binding may contribute to enhanced inhibition of dentate granule cells demonstrated electrophysiologically in kindled animals.
\end{abstract}

Kindling, an animal model of temporal lobe epilepsy, is a phenomenon in which repeated subconvulsive electrical stimulation results in progressively more intense seizures and eventually generalized motor convulsions (Goddard et al., 1969). Once established, the kindling effect is permanent.

Benzodiazepines are potent anticonvulsants which suppress kindled seizures and retard kindling development (for review, see McNamara et al., 1985). These anticonvulsant effects are presumably mediated at least in part through benzodiazepine receptors which are coupled to $\gamma$-aminobutyric acid (GABA) receptors in a macromolecular protein complex (Costa et al., 1979; Gavish and Snyder, 1981; Sigel and Barnard, 1984). GABA neurotransmission is enhanced by benzodiazepines (Choi et al., 1977). GABA agonist

Received December 28, 1984; Kevised March 12, 1985;

Accepted March 19, 1985

\footnotetext{
${ }^{1}$ This work was supported by Grants NS 16431 and NS 17771 from the National Institutes of Health and a grant from the Veterans Administration. We thank Ms. Cloise Pittman for her help in preparing the manuscript.

${ }^{2}$ To whom correspondence should be addressed.
}

and GABA transaminase inhibitors, which presumably enhance GABA neurotransmission, also exert anticonvulsant effects in the kindling model (for review, see McNamara et al., 1985).

Previous work from our laboratory demonstrated an increase in benzodiazepine receptor binding in the hippocampal membranes from kindled animals (McNamara et al., 1980). This increase was further localized to the dentate granule cells (Valdes et al.. 1982). Therefore, we hypothesized that benzodiazepine receptor alterations would be paralleled by GABA receptor alterations in kindled animals.

To test this hypothesis, we utilized quantitative radiohistochemical methods and examined benzodiazepine and GABA receptor binding in sections obtained from the same animals. We compared benzodiazepine and GABA receptor binding with regard to brain region specificity, time course, and cellular localization.

\section{Materials and Methods}

Preparation of animals for radiohisfochemistry. Adult male SpragueDawley rats (Charles River Breeding Laboratories), weighing between 300 and $425 \mathrm{gm}$, were stereotaxically implanted with a bipolar electrode in the right amygdala or right cntorhinal cortex under pentobarbital anesthesia as previously described (McNamara, 1978). After a postoperative recovery period of at least 7 days, electrical stimulations were administered at daily intervals and kindling developed as previously reported (McNamara et al., 1980). Unless specified otherwise, experimental animals exhibited three kindled seizures (class 4 or 5 (Racine, 1972)), the clonic motor component of which was at least $20 \mathrm{sec}$ in duration. These animals will be referred to as "kindled." These animals were sacrificed $24 \mathrm{hr}$ or 28 days after the last kindled seizure. Control animals underwent electrode implantation but were not stimulated.

A paired control was sacrificed with each experimental animal. Brains were rapidly removed and frozen by slow immersion into isopentane chilled in a methanol-dry ice bath. Coronal frozen sections $(10 \mu \mathrm{m})$ were cut in a cryostat microtome (Harris Mfg. Co.) and thaw-mounted on subbed glass slides. Slide-mounted sections were stored at $-70^{\circ} \mathrm{C}$ until incubation. Electrode placements were verified by methyl green pyronine $Y$ stain of frozen coronal sections.

$\left[{ }^{3} H\right]$ Muscimol binding. Upon removal from the freezer, slide mounted sections were allowed to rehydrate for $15 \mathrm{~min}$ at room temperature and were then fixed in $0.1 \%$ formalin in $50 \mathrm{~mm}$ Tris-citrate buffer $(\mathrm{pH} \mathrm{7.0)}$ for $10 \mathrm{~min}$ at $23^{\circ} \mathrm{C}$. Io promote removal of endogenous GABA, the sections were subsequently preincubated in $50 \mathrm{~mm}$ Tris-citrate buffer at $4^{\circ} \mathrm{C}$ for $15 \mathrm{~min}$. the standard incubation was carried out for $30 \mathrm{~min}$ at $4^{\circ} \mathrm{C}$ in a solution containing $10 \mathrm{~nm}\left[{ }^{3} \mathrm{H}\right]$ muscimol and $50 \mathrm{~mm}$ Tris-citrate (Fig. 1). Binding obtained in the presence of $100 \mu \mathrm{M}$ nonradioactive GABA was defined as nonspecific binding. Incubation was terminated by three consecutive 5 -sec rinses in a $50 \mathrm{~mm}$ Tris-citrate buffer at $4^{\circ} \mathrm{C}$. Slide-mounted sections were then briefly dipped in cold deionized water and were quickly dried under a stream of cold air.

$\left[{ }^{3} \mathrm{H}\right]$ Flunitrazepam binding. Methods used for $\left[{ }^{3} \mathrm{H}\right]$ flunitrazepam (FLU) were as described previously (Valdes et al., 1982), using 2 nм [ $\left.{ }^{3} \mathrm{H}\right] \mathrm{FLU}$ (Fig. 2). In additional experiments, incubation was carried out for $80 \mathrm{~min}$ at $4^{\circ} \mathrm{C}$ in $170 \mathrm{~mm}$ Tris- $\mathrm{Cl}$ buffer $(\mathrm{pH} 7.6)$ containing $0.5 \mathrm{nM}\left[{ }^{3} \mathrm{H}\right] \mathrm{FLU}$ in the absence or 
presence of $10 \mu \mathrm{M}$ muscimol and $200 \mathrm{nM}$ CL218,872. Binding obtained in the presence of $2.5 \mu \mathrm{M}$ diazepam was defined as nonspecific.

Quantitative radiohistochemistry. Tritium-sensitive film (LKB Ultrofilm) was apposed to the dried sections along with tritium standards in $\mathrm{x}$-ray cassettes for 10 days to 6 weeks at $4^{\circ} \mathrm{C}$. Film was developed in Kodak D-19, fixed in Kodak Rapid Fix at $18^{\circ} \mathrm{C}$, and mounted on clean glass slides for densitometric measurements. Sections were again apposed to emulsion-coated coverslips (Kodak NTB2 emulsion, 1:1 dilution) and exposed at $4^{\circ} \mathrm{C}$ for 4 to 6 weeks and processed in Kodak D-19 and regular fixer at $18^{\circ} \mathrm{C}$ for darkfield microscopy and silver grain counting.

Quantitation of the optical density measurements was accomplished as described previously from this laboratory (Savage et al., 1985) with minor modifications. $\left[{ }^{3} \mathrm{H}\right]$ Ornithine was used for tritium standards. Radioactivity of the standards was expressed as counts per minute per milligram of protein. The standard curve was linear over the range of optical density measurements made in this study.

Biochemical validation of radiohistochemical methods. Experiments were performed to demonstrate that binding to slide-mounted sections was equivalent to binding to brain membranes. Frozen sections $(10 \mu \mathrm{m})$ were obtained from naive male Sprague-Dawley rats. Slide-mounted sections were processed as described for the radiohistochemistry above until completion of the postincubation rinses. At this point the wet sections were wiped onto Whatman GF/B filters and the radioactivity of the filters was determined with a liquid scintillation counter.

Validation of the $\left[{ }^{3} \mathrm{H}\right] \mathrm{FLU}$ binding to slide-mounted sections in this laboratory was previously reported (Valdes et al., 1982). Specific binding, defined as total minus nonspecific binding, accounted for at least $95 \%$ of total binding. Displacement of $\left[{ }^{3} \mathrm{H}\right] \mathrm{FLU}$ binding by $\mathrm{CL} 218,872$ was similar to that described previously by others (Young et al., 1981).

Specific binding of $\left[{ }^{3} \mathrm{H}\right]$ muscimol accounted for at least $89 \%$ of total binding. Association and dissociation rates were similar to those reported for brain membranes (Olsen and Snowman, 1982). Equilibrium-binding isotherms were prepared using multiple concentrations between 0.5 and $100 \mathrm{nM}\left[{ }^{3} \mathrm{H}\right]$ muscimol. Computer analysis of the binding isotherm using the SCTFIT program (Hancock et al., 1979) disclosed that the data fitted best to a twosite model with high affinity $K_{D}$ of $1.6 \mathrm{nM}$ and a low affinity $K_{\mathrm{D}}$ of $94 \mathrm{~nm}$. Displacement of $\left[{ }^{3} \mathrm{H}\right]$ muscimol binding by GABA, imidazole acetic acid, and ( \pm )-bicuculline methiodide disclosed $\mathrm{IC}_{50}$ values of $40 \mathrm{nM}, 340 \mathrm{~nm}$, and 28 $\mu \mathrm{M}$, respectively; the relative potencies were in good agreement with the findings of others (Palacios et al., 1980).

Quantitation of benzodiazepine receptor subtypes. In preliminary biochemical experiments to validate the radiohistochemical method, we obtained the following values: $K_{\mathrm{D}}$ for FLU, $2.3 \mathrm{nM}, K_{\mathrm{i} 1}, 13.3 \mathrm{nM}$, and $K_{\mathrm{i} 2}, 600 \mathrm{~nm}$ for CL218,872. At concentrations of $\left.0.5 \mathrm{~nm} \mathrm{[}{ }^{3} \mathrm{H}\right] \mathrm{FLU}$ and $200 \mathrm{~nm} C L 218,872$, based on the law of mass action (Goodman et al., 1980), 1.34\% of type 1 receptors and $14 \%$ of type 2 receptors will bind $\left[{ }^{3} \mathrm{H}\right] \mathrm{FLU}$, whereas in the absence of CL218,872, $18 \%$ of either receptors will bind $\left[{ }^{3} \mathrm{H}\right] \mathrm{FLU}$. Then, a formula can be set up to calculate the percentage of type 1 receptors in a region: $\left(1.34 B m_{1}+14 B m_{2}\right) / 18 B m=F$, where $B m_{1}=$ total number of type 1 receptors, $B m_{2}=$ total number of type 2 receptors, $B m=$ total number of benzodiazepine receptors, and $F=\left(\left[{ }^{3} \mathrm{H}\right] \mathrm{FLU}\right.$ binding with $\left.\mathrm{CL} 218,872\right) /\left(\left[{ }^{3} \mathrm{H}\right]\right.$ FLU binding without CL218,872). Assuming no cooperativity between type 1 and type 2 receptors and assuming $B m=B m_{1}+B m_{2}$, the formula can be rearranged to give the fraction of type 1 receptors, $B m_{1} / B m=(14-18$ F)/(14 - 1.34).

Materials. Radioligands were purchased from New England Nuclear. GABA and imidazole acetic acid were purchased from Sigma Chemical Company. ( \pm )-Bicuculline methiodide was purchased from Pierce Chemical Company. Pentobarbital was purchased from Abbott Pharmaceuticals. CL218,872 was a gift from Dr. Claus Braestrup.

\section{Results}

GABA receptor binding. $\left[{ }^{3} \mathrm{H}\right]$ Muscimol binding was increased by $22 \%(p<0.001)$ in the fascia dentata of kindled animals sacrificed $24 \mathrm{hr}$ after the last kindled seizure (Table I). No significant changes

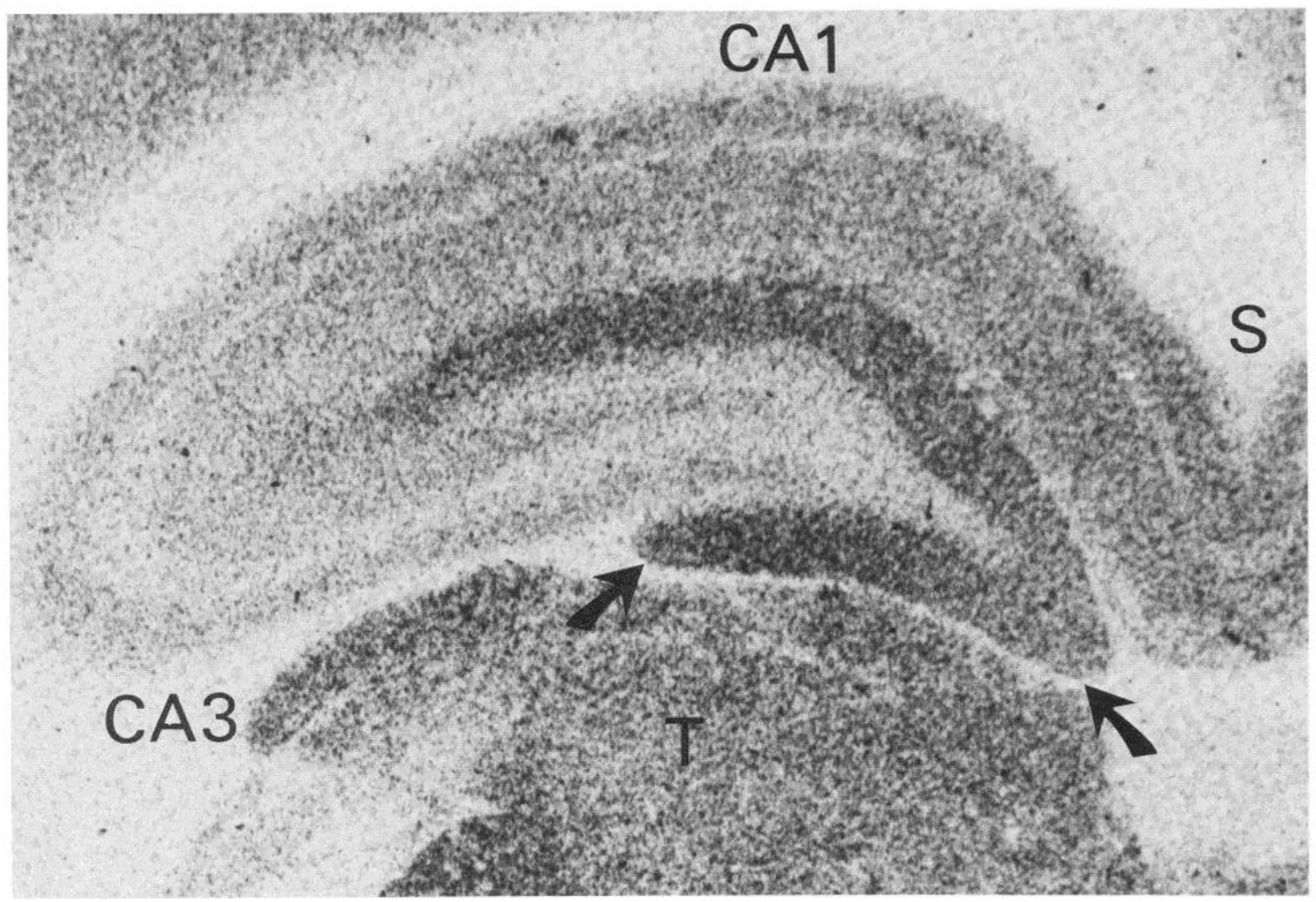

Figure 1. $\left[{ }^{3} \mathrm{H}\right]$ Muscimol autoradiograph of hippocampal formation using tritium-sensitive LKB Ultrofilm. This represents the total binding with $10 \mathrm{nM}\left[{ }^{3} \mathrm{H}\right]$ muscimol. The section representing nonspecific binding (not shown) is not readily differentiated from the background of the film. Densitometric data presented in Tables I and II were taken from stratum moleculare of the infrapyramidal blade of fascia dentata (arrows). Structures identified include hippocampal areas CA3 and CA1, subiculum $(S)$, and thalamus $(T)$. Magnification $\times 40$. 


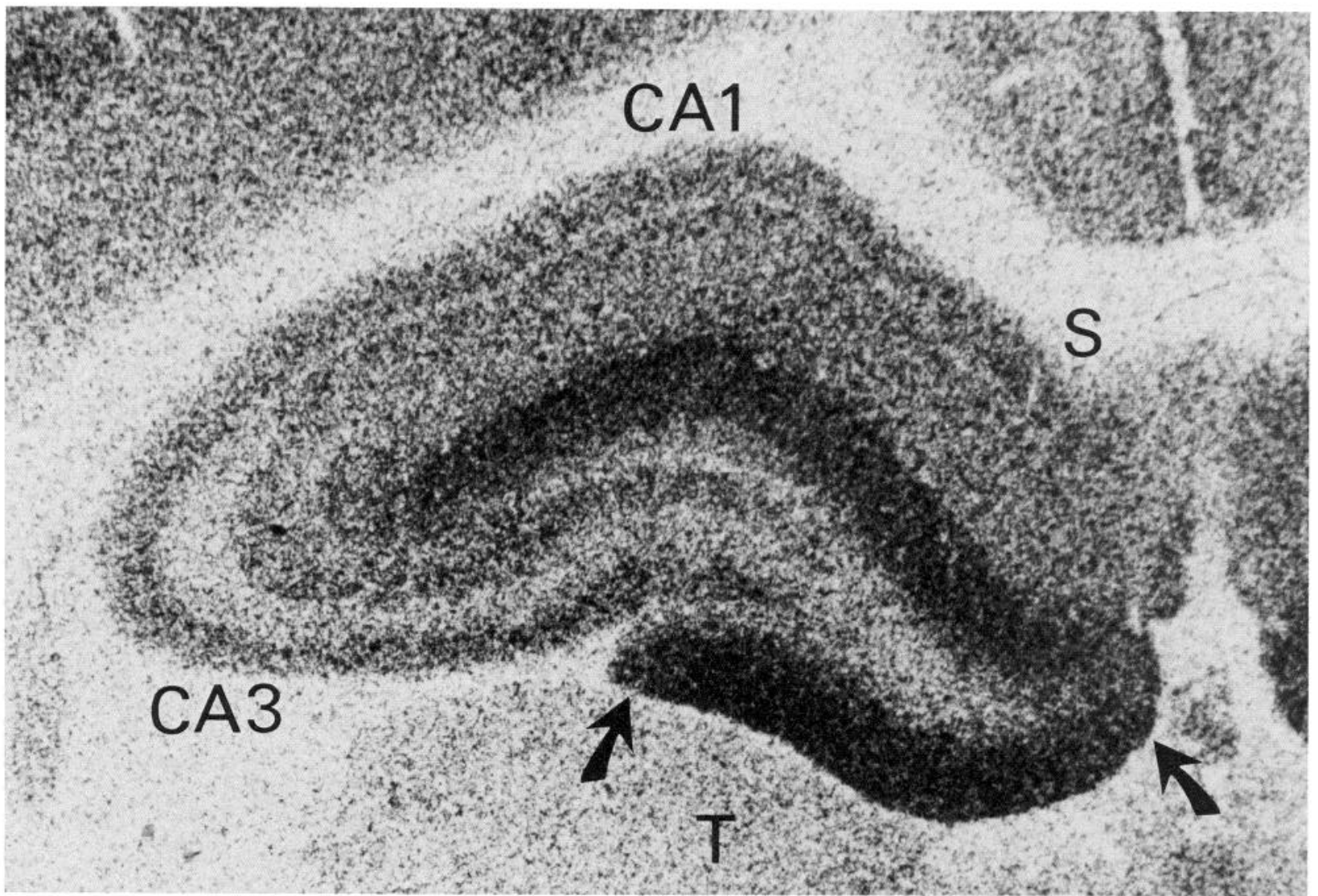

Figure 2. $\left[{ }^{3} \mathrm{H}\right] \mathrm{FLU}$ autoradiograph of hippocampal formation. This represents the total binding with $2 \mathrm{~nm}\left[{ }^{3} \mathrm{H}\right] \mathrm{FLU}$. The nonspecific binding was indistinguishable from background (not shown). Optical density measurements were made in stratum moleculare of the infrapyramidal blade of fascia dentata (arrows). S, subiculum; $T$, thalamus. Magnification $\times 40$.

TABLE I

Time course of GABA and benzodiazepine receptor binding in fascia dentata

Values represent the mean \pm SEM in femtomoles specifically bound per milligram of protein. The number $(n)$ of pairs of animals analyzed in each group is given. Left and right fascia dentata in each experimental animal were analyzed separately, each paired to the ipsilateral fascia dentata of respective controls.

\begin{tabular}{|c|c|c|c|}
\hline & & \multicolumn{2}{|c|}{$\begin{array}{l}\text { Time After the Last Kindled } \\
\text { Seizure }\end{array}$} \\
\hline & & 24 Hours & 28 Days \\
\hline$\left[{ }^{3} \mathrm{H}\right]$ Muscimol (10 nm) & $\begin{array}{l}\text { Kindled } \\
\text { Control }\end{array}$ & $\begin{array}{l}2533 \pm 191^{a} \\
2070 \pm 163 \\
(n=4)^{b}\end{array}$ & $\begin{array}{l}2282 \pm 59 \\
2136 \pm 52 \\
(n=3)\end{array}$ \\
\hline$\left[{ }^{3} \mathrm{H}\right] \mathrm{FLU}(2 \mathrm{~nm})$ & $\begin{array}{l}\text { Kindled } \\
\text { Control }\end{array}$ & $\begin{array}{l}1719 \pm 21^{a} \\
1246 \pm 26 \\
(n=3)\end{array}$ & $\begin{array}{l}1431 \pm 89 \\
1378 \pm 32 \\
(n=3)\end{array}$ \\
\hline
\end{tabular}

${ }^{a}$ Significantly different from control $(\rho<0.001$, two-tailed paired $t$ test); all others, $p>0.1$.

${ }^{b}$ One pair of entorhinal kindled animals was included here as they demonstrated the same alterations with kindling as the animals kindled from amygdala.

in $\left[{ }^{3} \mathrm{H}\right]$ muscimol binding were detected in the CA1 area of hippocampal formation, lamina IV of left neocortex, or pars reticulata of substantia nigra (data not shown). The increase in binding was transient, since no significant increases were detectable at 28 days after the last seizure (Table I).

To determine whether there was an increase in the number of $\left[{ }^{3} \mathrm{H}\right]$ muscimol-binding sites or an increase in affinity, binding isotherms were performed with radiohistochemical methods in two pairs of kindled and control animals. An increase of $\left[{ }^{3} \mathrm{H}\right]$ muscimol binding was present in the fascia dentata of the kindled animals at all concentrations used (data not shown). The limited number of data points (eight concentrations between 0.5 and $100 \mathrm{~nm}$ ) did not permit adequate separation of high and low affinity sites, thereby precluding definitive statements regarding a selective alteration of number or affinity of either of the putative sites. In addition, the possibility that the increased $\left[{ }^{3} \mathrm{H}\right]$ muscimol binding reflects increased availability of GABA receptor-binding sites due to a decrease in bound endogenous GABA in kindled animals cannot be excluded by the present experiments.

To localize more precisely the increased $\left[{ }^{3} \mathrm{H}\right]$ muscimol binding within the fascia dentata, a detailed analysis was performed of the distribution of silver grains developed with the emulsion-coated coverslip method. The laminar organization of the principal neurons and their afferents in the fasica dentata permit correlation of the distribution of the silver grains with the distribution of known cellular elements. These analyses disclosed similar percentage increases of silver grain counts over stratum granulosum and the inner, middle, and outer thirds of stratum moleculare (Fig. 3). The increase of silver grain density stopped abruptly at the hippocampal fissure and below stratum granulosum as evidenced by the absence of significant change in subregions of CA1 and in the hilus of fascia dentata. The distribution of the increased number of silver grains coincides with the somata and dendritic trees of the dentate granule cells, a distribution identical to that previously described with benzodiazepine receptors (Valdes et al., 1982).

Benzodiazepine receptor binding. $\left[{ }^{3} \mathrm{H}\right] \mathrm{FLU}$ binding was increased by $38 \%(p<0.001)$ in the fascia dentata of kindled animals 


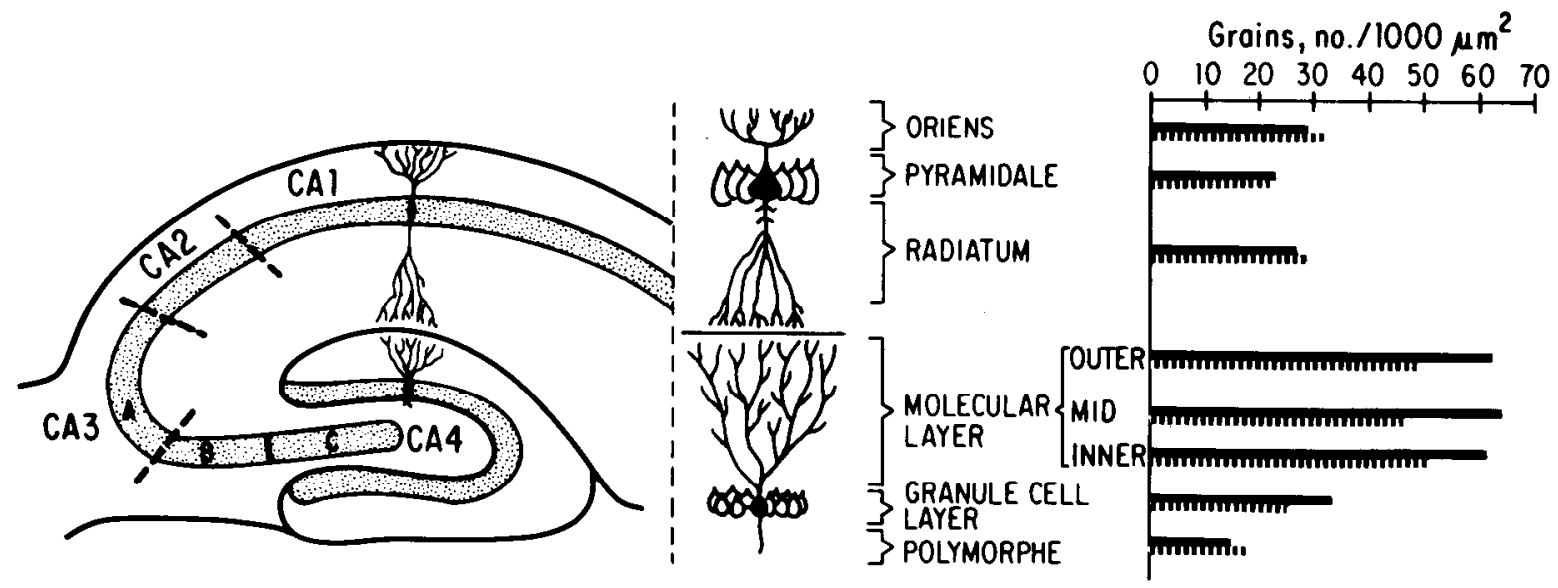

Figure 3. Regional distribution of $\left[{ }^{3} \mathrm{H}\right]$ muscimol binding in hippocampus of kindled and control animals. Left, Cross-section of rat hippocampal formation with subfields denoted according to the system of Lorente de No (1934). Center, Laminae of area CA1 and fascia dentata according to the system of Ramón y Cajal (1968) shown in relationship to a schematic pyramidal (CA1) or granule (fascia dentata) cell. Right, Silver grain counts of [ $\left.{ }^{3} \mathrm{H}\right] \mathrm{muscimol}$ autoradiographs by emulsion-coated coverslip methods from control and kindled animals. Dotted line, control; solid line, kindled.

sacrificed $24 \mathrm{hr}$ after the last kindled seizure (Table I). No significant changes in binding were present in the left neocortex (kindled, 1125 \pm 16 ; control, $1148 \pm 30 \mathrm{fmol} / \mathrm{mg}$ of protein) or substantia nigra pars reticulata (Table $\|)$. The time course of the increase in $\left[{ }^{3} \mathrm{H}\right] \mathrm{FLU}$ binding was similar to that of $\left[{ }^{3} \mathrm{H}\right]$ muscimol binding, since no significant increases were detected at 28 days after the last seizure (Table l).

To further explore the molecular properties of the seizure-induced increase of benzodiazepine receptors, we determined whether the increase selectively involved type 1 or type 2 benzodiazepine receptors (Lippa et al., 1979). To address this question, a relatively selective type 1 benzodiazepine ligand, a triazolopyridazine, CL218,872, was utilized. Based on the results of the binding studies (Table II), utilizing the formula described under "Materials and Methods," the proportions of type 1 benzodiazepine receptor were calculated. In the control animals, only $3 \%$ of all benzodiazepine receptors in the fascia dentata were type 1 , whereas $52 \%$ in the substantia nigra pars reticulata were type 1 . These values are in agreement with others' results regarding regional distribution of these subtypes of benzodiazepine receptors (Young et al., 1981; Unnerstall et al., 1982; Lo et al., 1983). Importantly, percentages remained unchanged with kindling. Since fascia dentata contains almost exclusively type 2 receptors, the increase in [ $\left.{ }^{3} \mathrm{H}\right] \mathrm{FLU}$ binding was mostly due to an increase of type 2 receptors, although a concomitant increase of type 1 receptors cannot be rulcd out. In the substantia nigra, proportions of type 1 and 2 receptors remained unaltered with kindling.

GABA and benzodiazepine receptor coupling. The parallel increases of $\left[{ }^{3} \mathrm{H}\right]$ muscimol and $\left[{ }^{3} \mathrm{H}\right] \mathrm{FLU}$ binding and the similar time course and cellular localization of these alterations raised the possibility that the coupling of GABA and benzodiazepine receptors was also increased in the kindled animals. To examine this possibility, the enhancement of $\left[{ }^{3} \mathrm{H}\right] \mathrm{FLU}$ binding by muscimol was investigated in the fascia dentata. The pars reticulata of substantia nigra was examined as a control, since no kindling-related changes in $\left[{ }^{3} \mathrm{H}\right] \mathrm{FLU}$ or [ $\left.{ }^{3} \mathrm{H}\right]$ muscimol were found in this region (Table II).

Contrary to our expectations, no increase in coupling was found. Indeed, in the fascia dentata, the muscimol enhancement of $\left[{ }^{3} \mathrm{H}\right]$ FLU binding in kindled animals (45\%) was less than that in control $(54 \%)$, a difference which actually reached statistical significance ( $p<0.05$, Student's two-tailed $t$ test). In the substantia nigra, the enhancement was slightly more in kindled $(57 \%)$ than in control animals $(51 \%)$ ( $p>0.1$, Student's two-tailed $t$ test). No subtypespecific alterations in receptor coupling could be found with the addition of CL218,872.

In fact, in substantia nigra, in the presence of CL218,872, musci-
TABLE ॥

$\left[{ }^{3} \mathrm{H}\right]$ Flunitrazepam binding in kindled animals

Values represent the mean \pm SEM in femtomoles specifically bound per milligram of protein. Data for fascia dentata were obtained from two pairs of amygdala-kindled animals and one pair of entorhinal-kindled animals. Data for substantia nigra were obtained from four pairs of amygdala-kindled animals and one pair of entorhinal-kindled animals. In both areas entorhinalkindled animals yielded data comparable to those of amygdala-kindled animals and data were pooled. Concentrations of ligands used in incubation during binding assays were: $\left[{ }^{3} \mathrm{H}\right] \mathrm{FLU}, 0.5 \mathrm{nM}$, muscimol, $10 \mu \mathrm{M}$, and CL218,872, $200 \mathrm{~nm}$

\begin{tabular}{llcc}
\hline \multicolumn{1}{c}{ I igands } & Condition & Fascia Dentata & Substantia Nigra \\
\hline$\left.{ }^{3} \mathrm{H}\right] \mathrm{FLU}$ & Kindled & $1049 \pm 30$ & $488 \pm 16$ \\
& Control & $810 \pm 4$ & $508 \pm 18$ \\
& (\% Change) & $(+30)^{\mathrm{a}}$ & $(-4)$ \\
& Kindled & $1517 \pm 33$ & $766 \pm 18$ \\
$\left.{ }^{3} \mathrm{H}\right] \mathrm{FLU}$ & Control & $1248 \pm 9$ & $765 \pm 26$ \\
Muscimol & $(\%$ Change) & $(+22)^{\mathrm{a}}$ & $(0)$ \\
& Kindled & $820 \pm 14$ & $209 \pm 6$ \\
$\left.{ }^{3} \mathrm{H}\right] \mathrm{FLU}$ & Control & $619 \pm 12$ & $210 \pm 16$ \\
CL218,872 & $(\%$ Change) & $(+32)^{\mathrm{a}}$ & $(0)$ \\
& Kindled & $1081 \pm 28$ & $170 \pm 7$ \\
$\left.{ }^{3} \mathrm{H} \mathrm{H}\right] \mathrm{FLU}$ & Control & $856 \pm 26$ & $175 \pm 5$ \\
CL218,872 & (\% Change) & $(+26)^{a}$ & $(-3)$ \\
Muscimol &
\end{tabular}

${ }^{a}$ Significantly increased with kindling over control, $p<0.001$ (two-tailed paired $t$ test).

mol reduced the binding of $\left[{ }^{3} \mathrm{H}\right] \mathrm{FLU}$. This suggests that muscimol increased the affinity of CL218,872 more than that of $\left[{ }^{3} \mathrm{H}\right] \mathrm{FLU}$ to both type 1 and type 2 benzodiazepine receptors.

\section{Discussion}

The principal findings of this study are: (1) GABA receptor binding is increased in the fascia dentata but not in several other areas of the kindled rat brain; (2) the anatomic distribution of the increased GABA receptor binding in fascia dentata is consistent with a localization to the somata and dendritic trees of the granule cells; (3) the direction, anatomic distribution, and time course of the increased GABA receptor binding are paralleled by increases of benzodiazepine receptor binding; (4) despite the increased GABA receptor binding, GABA receptor-mediated enhancement of benzodiazepine receptor binding is slightly decreased in the fascia dentata of kindled rats; and (5) the kindled seizure-induced increase of benzodiazepine receptor binding in fascia dentata is due mainly to an increase in 
type 2 receptors; no change in the percentage of subtypes was detected in substantia nigra.

The distribution of this seizure-induced increase in GABA receptor binding in stratum granulosum and throughout stratum moleculare supports a localization to the somata and dendritic trees of the dentate granule cells. This pattern does not coincide with the distribution of either of the principal granule cell afferents, namely, the perforant path (outer two-thirds of stratum moleculare) or commissural/associational (inner one-third of stratum moleculare) fibers (Blackstad, 1956; Gottlieb and Cowan, 1973; Steward, 1976; Wyss, 1981). Likewise, this pattern does not conform to the distribution of blood vessels in fascia dentata. Localization to glia seems unlikely because of the distinct laminar distribution of the increase together with the absence of $\mathrm{Na}^{\prime}$-independent GABA receptor binding in primary glial cultures (Ossola et al., 1980). Localization to interneurons seems less likely, since the number of granule cells vastly exceeds the number of interneurons. The distribution of the seizureinduced increase in GABA receptor binding is identical to the seizureinduced increases of benzodiazepine receptor binding which have also been tentatively localized to the dentate granule cells (Valdes et al., 1982).

The striking parallel in the seizure-induced increases in GABA and benzodiazepine receptor binding is not surprising in view of the extensive evidence linking these two sites to the same macromolecular complex. Paradoxically, the increased GABA receptor binding is not paralleled by increased responsiveness of the benzodiazepine receptors to exogenous $G A B A$; indeed the kindled animals exhibited a slight decrease in magnitude of GABA enhancement of benzodiazepine binding compared to controls. This result confirms our previous finding in well washed membranes prepared from microdissected fascia dentata of kindled animals (Fanelli and McNamara, 1983). Essential to the understanding of this apparent conflict is that radioligand binding with $\left[{ }^{3} \mathrm{H}\right]$ muscimol interacts with a high affinity GABA receptor, whereas GABA regulation of benzodiazepine receptor binding reflects a low affinity GABA receptor. One possible explanation is that the increased $\left[{ }^{3} \mathrm{H}\right]$ muscimol binding represents desensitized GABA receptors which are functionally uncoupled. Alternatively, the seizure-induced increase of benzodiazepine receptors may be in a conformational state reflecting the highest affinity for benzodiazepines, and added GABA cannot increase this affinity further.

The tentative localization of seizure-induced increases of GABA and benzodiazepine receptor binding to dentate granule cells raises the possibility that these molecular alterations may underlie alterations of granule cell physiology. Indeed the granule cells receive both feed-forward and recurrent inhibition which appear to be mediated by GABA (Buzsaki and Czeh, 1981; Douglas et al., 1983 Tuff et al., 1983; Fricke and Prince, 1984). To test this idea, G. L. King and R. Dingledine, in collaboration with this laboratory, employed field potential recordings to examine the responses of granule cells to orthodromic and antidromic activation in isolated hippocampal slices prepared from kindled animals $24 \mathrm{hr}$ after the last seizure (King et al., 1985). Increases were apparent in tests of both feedforward and recurrent inhibition of granule cells in kindled animals as compared to controls. The increased inhibition was almost certainly synaptic and GABA mediated. Likewise, Tuff et al. (1983) found enhanced paired-pulse inhibition of granule cells in vivo following kindling. Liebowitz et al. (1977) have reported increased GABA release from hippocampal slices from kindled animals; it is not clear whether this reflects synaptic release and whether it is from fascia dentata and/or hippocampus proper. Nevertheless, it seems reasonable to speculate that the increased release of GABA, together with the increase of GABA and benzodiazepine receptor binding, may contribute, at least in part, to the enhanced inhibition of dentate granule cells demonstrated electrophysiologically.

A final paradox deserving of comment is that the direction of the biochemical changes together with the electrophysiology point to an increase of inhibition of granule cells in the kindled animals. This would certainly argue against the idea that these biochemical changes constitute the molecular basis of kindling; indeed the transient nature of the GABA receptor increase is more consistent with a response of the brain to repeated seizures. Lesion data support the idea that the hippocampal formation plays a facilitatory role in kindling development (Dasheiff and McNamara, 1982; Savage et al., 1985). The granule cells of fascia dentata, as a gateway and rate-limiting step to the flow of information through the hippocampal trisynaptic circuit (Winson and Abzug, 1978), would then be an appropriate site of endogenous modulation. We propose that the increases in GABA and benzodiazepine receptors represent part of a carefully orchestrated response of the brain to repeated seizures, designed to stabilize granule cell excitability and reduce the likelihood of hippocampal activation and subsequent seizures.

\section{References}

Blackstad, T. W. (1956) Commissural connections of the hippocampal region in the rat, with special reference to their mode of termination. J. Comp. Neurol. 105: 417-537.

Buzsaki, G., and G. Czeh (1981) Commissural and perforant path interactions in the rat hippocampus. Exp. Brain Res. 43: $429 \times 438$

Choi, D. W., D. H. Farb, and G. D. Fischbach (1977) Chlordiazepoxide selectively augments GABA action in spinal cord cell cultures. Nature 269: 342-344.

Costa, T., D. Rodbard, and C. B. Pert (1979) is the benzodiazepine receptor coupled to a chloride anion channel? Nature 277: 315-317.

Dasheitt, R. M., and J. O. McNamara (1982) Intradentate colchicine retards the development of amygdala kindling. Ann. Neurol. 11: 347-352.

Douglas, R. M., B. L. McNaughton, and G. V. Goddard (1983) Commissural inhibition and facilitation of granule cell discharge in fascia dentata. $J$. Comp. Neurol. 219: 285-294.

Fanelli, R. J., and J. O. MCNamara (1983) Kindled seizures result in decreased responsiveness of benzodiazepine receptors to $\gamma$-aminobutyric acid (GABA). J. Pharmacol. Exp. Ther. 226: 147-150.

Fricke, R. A., and D. A. Prince (1984) Electrophysiology of dentate gyrus granule cells. J. Neurophysiol. 51: 195-209.

Gavish, M., and S. H. Snyder (1981) $\gamma$-Aminobutyric acid and benzodiazepine receptors: Copurification and characterization. Proc. Natl. Acad. Sci. U. S. A. 78: 1939-1942.

Goddard, G. V., D. C. Mclntyre, and C. K. Leech (1969) A permanent change in brain function resulting from daily electrical stimulation. Exp. Neurol. 25 . 295-330.

Goodman, R. R., S. H. Snyder, M. J. Kuhar, and W. S. Young, III (1980) differentiation of delta and mu opiate receptor localizations by light microscopic autoradiography. Proc. Natl. Acad. Sci. U. S. A. 77: 6239-6243.

Gottlieb, D. I., and W. M. Cowan (1973) Autoradiographic studies of the commissural and ipsilateral association connections of the hippocampus and dentate gyrus of the rat. I. The commissural connections. J. Comp. Neurol. 119: 393-422.

Hancock, A. A., A. DeLean, and R. L. Lefkowitz (1979) Quantitative resolution of beta-adrenergic receptor subtypes by selective ligand binding: Application of a computerized model fitting technique. Mol. Pharmacol. 16: 19

King, G. L., R. Dingledine, J. L. Giacchino, and J. O. McNamara (1985) Abnormal neuronal excitability in hippocampal slices from kindled rats. $\mathrm{J}$. Neurophysiol., in press.

Liebowitz, N. R., R. A. Pedley, and R. W. P. Cutler (1977) Release of $\gamma$ aminobutyric acid from hippocampal slices of the rat following generalized seizures induced by daily electrical stimulation of entorhinal cortex. Brain Res. 138: 369-373

Lippa, A. S., J. Coupet, E. N. Greenblatt, C. A. Klepner, and B. Beer (1979) A synthetic non-benzodiazepine ligand for benzodiazepine receptors: $A$ probe for investigating neuronal substrates of anxiety. Pharmacol. Biochem. Behav. 11: 99-106.

Lo, M. M. S., D. L. Niehoff, M. J. Kuhar, and S. H. Snyder (1983) Differential localization of type I and type II benzodiazepine binding sites in substantia nigra. Nature 306: 57-60.

Lorente de Nó, R. (1934) Studies on the structure of the cerebral cortex. II Continuation of the study of the ammonic system. J. Psychol. Neurol. (Lpz.) 46: 113-177.

McNamara, J. O. (1978) Muscarinic cholinergic receptors participate in the kindling model of epilepsy. Brain Res. 154: 415-420.

McNamara, J. O., A. M. Peper, and V. Patrone (1980) Repeated seizures 
induce long-term increase in hippocampal benzodiazepine receptors. Proc. Natl. Acad. Sci. U. S. A. 77: 3029-3032.

McNamara, J. O., D. W. Bonhaus, B. J. Crain, R. L. Gellman, J. L. Giacchino, and C. Shin (1985) The kindling model of epilepsy: A critical review. CRC Crit. Rev. Clin. Neurobiol. in press.

Olsen, R. W., and A. M. Snowman (1982) Chloride-dependent enhancement by barbiturates of $\gamma$-aminobutyric acid receptor binding. J. Neurosci. 2: 1812-1823

Ossola, L., F. V. DeFeudis, and P. Mandel (1980) Lack of $\mathrm{Na}^{+}$-independent binding of $\left[{ }^{3} \mathrm{H}\right] \mathrm{GABA}$ or $\left[{ }^{3} \mathrm{H}\right]$ muscimol to particulate fractions of cultured astroblasts. J. Neurochem. 34: 1026-1029.

Palacios, J. M., W. S. Young, III, and M. J. Kuhar (1980) Autoradiographic localization of $\gamma$-aminobutyric acid (GABA) receptors in the rat cerebellum. Proc. Natl. Acad. Sci. U. S. A. 77: 670-674.

Racine, R. J. (1972) Modification of seizure activity by electrical stimulation. II. Motor seizure. Electroencephalogr. Clin. Neurophysiol. 32: 281-294.

Ramón y Cajal, S. (1968) The Structure of Ammon's Horn, L. M. Kraft, transl., Charles C Thomas, Springfield, IL.

Savage, D. D., L. C. Rigsbee, and J. O. McNamara (1985) Knife cuts of entorhinal cortex: Effects on development of amygdaloid kindling and seizure-induced decrease of muscarinic cholinergic receptors. J. Neurosci. 5: 408-413.

Sigel, E., and E. A. Barnard (1984) A $\gamma$-aminobutyric acid/benzodiazepine receptor complex from bovine cerebral cortex. J. Biol. Chem. 259: 7219 7223.

Steward, O. (1976) Topographic organization of the projections from the entorhinal area to the hippocampal formation of the rat. J. Comp. Ncurol. 167: 285-314.

Tuff, L. P., R. J. Racine, and R. Adamec (1983) The effects of kindling on GABA-mediated inhibition in the dentate gyrus of the rat. I. Paired-pulse depression. Brain Res. 277: 79-90.

Unnerstall, J. R., D. L. Niehoff, M. J. Kuhar, and J. M. Palacios (1982) Quantitative receptor autoradiography using $\left[{ }^{3} \mathrm{H}\right]$ Ultrofilm: Application to multiple benzodiazepine receptors. J. Neurosci. Methods 6: 59-73.

Valdes, F., R. M. Dasheiff, F. Birmingham, K. A. Crutcher, and J. O. McNamara (1982) Benzodiazepine receptor increases after repeated seizures: Evidence for localization to dentate granule cells. Proc. Natl. Acad. Sci. U. S. A. 79: 193-197.

Winson, J., and C. Abzug (1978) Neuronal transmission through hippocampal pathways dependent upon behavior. J. Neurophysiol. 41: 716-732.

Wyss, J. M. (1981) An autoradiographic study of the efferent connections of the entorhinal cortex in the rat. J. Comp. Neurol. 199: 495-512.

Young, W. S., III, D. Niehoff, M. J. Kuhar, B. Beer, and A. S. Lippa (1981) Multiple benzodiazepine receptor localization by light microscopic radiohistochemistry. J. Pharmacol. Exp. Ther. 216: 425-430. 